Please find the final published version in Muqarnas, Vol 35(1), pp. 293-99 at

DOI: $\underline{10.1163 / 22118993 \_03501 P 013}$

MEHRAN MATIN AND MOUJAN MATIN

\begin{abstract}
A PRELIMINARY STUDY OF A NINETEENTH-CENTURY PERSIAN MANUSCRIPT
ON PORCELAIN MANUFACTURE IN THE SIPAHSALAR LIBRARY, TEHRAN
\end{abstract}

\title{
Abstract
}

The Risāla dar tafșīl-i sākhtan-i chinni (A Treatise on Porcelain Manufacture) is a Qajarperiod manuscript in Persian, housed at the Sipahsalar Library in Tehran. It is the only known source that details the modern technology of porcelain production in the Qajar era (1789-1925). According to the information in the colophon, the scribe, Masih ibn Muhammad Baqir al-Firuzabadi, completed the manuscript in the year 1284 (1868). The text mentions that it is the translation of a French work, but no further reference to the original book is given. The purpose of this essay is to introduce and review the Persian manuscript, to reveal its relation to the three-volume Traité des arts céramiques ou des poteries (Treatise on Ceramic Arts or Potteries) by Alexandre Brongniart, a nineteenthcentury scientist and director of the Sèvres Porcelain Factory, and to underline its importance to the history of art and technology in Qajar Iran.

Keywords: Qajar ceramics, porcelain, manuscript, Alexandre Brongniart, art school, Madrasa-i Nāṣirī, Dār al-Funūn

An unpublished Persian manuscript titled Risāla dar tafșîl-i sākhtan-i chīnī (A Treatise on Porcelain Manufacture) dating from the reign of Nasir al-Din Shah (r. 1848-1896) ${ }^{1}$ is in the collection of the Sipahsalar Library in Tehran (Kitābkhāna-i Madrasa-i ' $\bar{A} / \overline{\bar{l}}-\mathrm{y} i$ 
Sipahsālār, MS. 2833). ${ }^{2}$ The text implies that it is translated from a French work, but no reference to the original book or its author is given. The manuscript contains sixty-one folios; its opening chapter is titled Dar bāb-i sākhtan-i khamīrhā-yi chīn $\overline{\bar{I}}$ (On the Production of Porcelain Paste). Each page consists of eighteen lines written in black ink, overscored in red, in nasta 'liq script. There are a few notes in the margins throughout, all in black ink except those in folios $4 b$ and $19 a$, which appear in red. The signature of the scribe in the colophon is in blue ink. On the verso of each folio throughout the manuscript, in the bottom left corner, appears a catchword that repeats the first word of the following page. $^{3}$

\section{THE COLOPHON}

The colophon appears in the shape of a diamond on folio 61b (fig. 1). It indicates that the transcription of the manuscript was completed during the reign of Nasir al-Din Shah, in the Translation Bureau (Dār al-tarjuma), ${ }^{4}$ which had recently been established by the government. The colophon is signed by "Masih, son of Muhammad-Baqir al-Firuzabadi" and dated 24 Dhu'l-Hijja 1284 (April 18, 1868). The scribe's signature, in blue ink, produced a blot on the facing folio, suggesting that the manuscript was closed immediately after signing, before the ink dried.

Information on the identity of the scribe is scant. One account states that, under the chairmanship of I'tizad al-Saltana, ${ }^{5}$ Mirza Masih held a post in the Ministry of Science; ${ }^{6}$ another reports that he acted as head of the Press Bureau. ${ }^{7}$ Was he just the 
scribe of the manuscript, or was he also the translator? A clue appears on folio $60 \mathrm{~b}$, line 12. Here, the translator instructed the scribe to separate two words by a space that could be filled in later (fig. 2), but the scribe obviously took the comment to be part of the text and wrote it into the manuscript accordingly. This likely indicates that the translator and the scribe were not the same person.

\section{THE FIRST FOLIO}

Folio 1a is inscribed in three different hands, none of which is similar to that of the scribe

(fig. 3). (The main text of the manuscript begins on folio $1 \mathrm{~b}$.) The horizontally oriented inscription on the lower part of folio 1a is a quotation from Mu jam al-buldān (Dictionary of Countries) by the thirteenth-century geographer, Yaqut al-Hamawi (d. 1229). ${ }^{8}$ It contains no date but is signed at the bottom by the "Minister of Science" (waz ìr-i 'ulüm). I'tizad al-Saltana must therefore have been the writer of this inscription.

The second note is written diagonally just above the center of the page. It indicates that the manuscript was registered at the library of I'tizad al-Saltana, "Minister of Science, Industry, and Commerce," in Rabi' al-awwal 1285 (June-July 1868). Thus the manuscript entered the library two or three months after its completion (as recorded in the colophon). I'tizad al-Saltana's library was later bought by Mirza Husayn Khan Mushir al-Dawla Sipahsalar ${ }^{9}$ as part of endowment for the college he had already established (Madrasa-i Nāṣir $\overline{1}$, later known as Madrasa-i ' $\bar{A} \bar{l} \bar{I}-y i$ Sipahsālār). ${ }^{10}$ The manuscript remains there to this day.

Another diagonally written inscription appears at the top of the page. It comments 
on the transfer of the manuscript and its registration at the Madrasa-i Nāṣir $\bar{I}$ on Friday 15 Dhu'l-Hijja 1297 (November 19, 1880)_about one month before the death of I'tizad alSaltana—and includes details regarding the endowment documents.

Folio 1a also contains three seals—two rectangular and one oval—in black ink. The smaller rectangular seal contains only I'tizad al-Saltana's name. The larger rectangular seal contains the name Mushir al-Dawla Sipahsalar A'zam, surrounded by "endowed to the Nasiri Library (vaqf-i kitābkhāna-i Nāșirī nimud), Hajji Mirza Husayn Khan, the month of Dhu'l-Hijja." The oval seal mark is that of the Nasiri Library and indicates that the manuscript was transferred there in the year 1297 (1880).

\section{THE FRENCH ORIGINAL}

Although the source of the translation is never explicitly named, hints about it appear sporadically throughout the manuscript: The Persian text repeatedly states that the original work was in French. It mentions a first and second volume of the original, and occasionally gives page numbers. Additionally, it refers to its source as kitāb-i naqsha (book of drawings). ${ }^{11}$ Finally, it contains information about chemistry and ceramics that was considered pioneering in the nineteenth century; the number of scientists who could have written such a seminal treatise at the time was limited.

This and other lines of evidence lead us to argue that the original French text must have been the Traité des arts céramiques ou des poteries: Considérées dans leur histoire, leur pratique et leur théorie [Treatise on Ceramic Arts or Potteries: considerations of their history, their practice and their theory.] (hereafter Arts céramiques), by Alexandre 
Brongniart (fig. 4). ${ }^{12}$ Published in Paris in 1844, just three years before his death, the treatise was Brongniart's last major work. Arts céramiques comprises two volumes of text totaling approximately 1500 pages and a third volume, an atlas, that includes tables, charts, and illustrations. The first two volumes are divided into three books. The first book (in volume 1) provides a technical background to the study of ceramics. It discusses subjects such as etymology, historical origins, and geology, raw materials and formation, glazing, firing, and the properties of clays and glazes. The second book (divided between volumes 1 and 2) classifies pottery based on type of body (porous, vitrified, or translucent) and explores the technology of ceramics in different cultures and civilizations. The third book (in volume 2) focuses on coloring and decoration. Volume 3-the atlas-contains three parts: the first presents the charts and tables of collected data, the second provides a description of the illustrations, and the third includes the illustrations in eighty-six plates. This volume is a technical and visual reference work that supports the discussions of the first two volumes with clear and carefully rendered drawings.

A chief ceramicist at Sèvres, Alphonse Salvétat, edited two subsequent editions (1867 and 1877) of Arts céramiques, supplemented by his "notes and additions." No complete translation of Brongniart's work has been published in any language; only the section Coloration et décoration (volume 2, 507-684) has been translated, into English and German. The English translation was published in 1898, as a booklet titled Coloring and Decoration of Ceramic Ware. ${ }^{13}$ Its preface begins, "The writing of Alexander Brongniart marked an epoch in ceramic literature and remains a standard classic to the present day." In 1910, fifty-six years after the first publication of Arts céramiques, the significance of the work was noted in L. M. Solon's comprehensive bibliography, Ceramic 
Literature: An Analytical Index. ${ }^{14}$

If one single book had to be selected to represent ceramic literature in a miscellaneous library, if a student of pottery manufacture had to part with all of his technical works save one, we have no hesitation in saying that the choice should fall upon Brongniart's Traité des arts céramiques. Before Brongniart gave to the learned world a treatise which was to raise the potter's art to the level of a science, nothing but desultory attempts had been main to gain that end. ${ }^{15}$

The three volumes of Arts céramiques were definitive texts at the time of their publication. They provided thorough, clear, and important information on nineteenthcentury ceramics, including the most up-to-date technologies and developments. The Persian manuscript is a free translation of volumes 1 and 2 -folios $1 \mathrm{~b}-25 \mathrm{~b}$ from the first volume and folios $26 \mathrm{a}-61 \mathrm{~b}$ from the second. The chapters Terres cuites [common pottery] and Poteries tendres lustrées [glossy pottery] (volume 1, 300-592) were not translated, perhaps because they concern the history of ceramics in different civilizations, and the translator was more interested in scientific and technical issues. The general layout and order of chapters in the translated manuscript differ from those of the original text. In the Persian translation, unlike the original French work, the text is continuous rather than divided into chapters, sections, or sub-sections. Folio 60a of the Persian text, for example (fig. 5), is a translation of pages 430 and 431 of the French original, which describes a plate in the atlas (fig. 6). 


\section{CONCLUSION AND SIGNIFICANCE OF THE MANUSCRIPT}

Being a translation of a technical book, it is evident that Risāla dar tafșîl-i sākhtan-i chīnī was never going to be popular reading, especially during the Naseri period. Rather, the commissioning of this manuscript reflects the strong desire of the Qajar court to master the modern technology of porcelain production, so as to apply it to local practices in Iran. ${ }^{16}$ One valuable feature of the manuscript is that it provides translations of technical terms from French to Persian (see table). These translations are significant for studies of historical texts on minerals and materials, generally known as Gawharnāma, or Jawā hirnāma; the term tabāsh $\bar{r} r$ (magnésie), for instance, seems to have been in use in Gawharnāmas since medieval and post-medieval Islamic periods. In contrast, the Persian translations of some of the modern French terms-for instance, jush-i bulürkhāna for frittes vitreuses, and khākhā-yi pukhta for charmot-are among the earliest examples of their use.

The mention of the term urane (uranium) in the manuscript (Persian üran) provides important links with a specific type of Qajar ceramics. Recently, scientific analysis of tiles signed by 'Ali Muhammad Isfahani have demonstrated that their yellow and green pigments contain significant amounts of uranium. ${ }^{17}$ The use of uranium pigment, unprecedented in Persian ceramic technology, suggests that the Persian translation of the Arts céramiques manuscript played a key role in the development of Qajar ceramic practices.

Variously known as "Qajar art pottery,"18 "Tehran art pottery,"19 and "Qajar Art 
School ceramics," 20 this group of ceramics, including both tiles and vessels, was produced mainly in Tehran in the second half of the nineteenth century, and imitated underglaze-painted and luster-decorated Safavid and Ilkhanid predecessors. Contrary to the general notion that ceramic practices in Iran experienced a stylistic and technical decline during the Qajar period, Qajar Art School ceramics are qualitatively outstanding. One of the best-known makers of such ceramics was the abovementioned 'Ali Muhammad Isfahani. ${ }^{21}$ Originally from Isfahan, he migrated to Tehran and established his workshop near the Gate of Shahzada 'Abd al-'Azim in the 1880s. Samples of his signed works are in the Shahzada 'Abd al-'Azim Shrine (Tehran), the Shayhk 'Abd alNabi Nuri Mosque (Tehran), the Victoria and Albert Museum (London), and the National Museum of Scotland (Edinburgh), among others.

Many aspects of the origin and development of Qajar Art School ceramics remain unclear. It has been suggested that their makers were trained by Western specialists at educational establishments such as the Dar al-Funun ${ }^{22}$ during the Qajar period, ${ }^{23}$ but little evidence has been found to support this supposition. The previously unnoted Persian manuscript introduced in this study is one of the few documents providing evidence regarding the links between Qajar Art School ceramics and contemporary French technology. We hope that our preliminary analysis of this primary source will stimulate new directions of research in the history and technology of nineteenth-century ceramics in Iran.

\author{
Mehran Matin \\ Independent Scholar, Tehran
}


Moujan Matin

Wolfson College, University of Oxford, Oxford

\section{NOTES}

Authors' note: We dedicate this essay to Professor Oliver Watson on the occasion of his retirement, and in recognition of his many outstanding contributions to the history of ceramics in Iran.

1. The fourth king of the Qajar Dynasty (1794-1925).

2. Aḥmad Munzavī, Fihrist-i nuskhahā-yi khațt î-yi fārs $\bar{I}$ (Tehran, 1969), 416, no. 3859, provides a description of the manuscript.

3. Catchwords (Persian rikāba) were used to make certain that the folios of the treatise were in the correct order.

4. The Translation Bureau (Dār al-tarjuma, Dār al-tarjuma-i Nāșirī, or Dār al-Tarjuma-i Kh $\bar{a} s ̦ s ̦ a-i$ dawlat $\bar{I}$ ) was a Nasiri-period cultural foundation devoted to translation of texts into Persian. The date of its establishment is unknown. In the year 1288 (1871-72), Muhammad Hasan Khan Sani' al-Dawla, also known as I'timad al-Saltana, was appointed director. Under his chairmanship, the bureau later became an important cultural and scientific foundation. See 'Abbas Amanat, "E'temad al-Salțana," Encyclopaedia Iranica, vol. 8 (1998), 662-66 (available online at http://www.iranicaonline.org/articles/etemad-al-saltana).

5. 'Aliquli Mirza I'tizad al-Saltana (1822-80), son of Fath-'Ali Shah Qajar, was an intelligent and well-educated prince. In 1856, he received the title I'tizād al-Saltana (Assistant of the Monarchy) from Nasir al-Din Shah, and two years later was appointed chancellor of the polytechnic college Dār al-Funün. Founded in 1851, the Dar al-Funun 
was first modern institution of higher education in Iran. See 'Ali Al-i Dawud, "I'tizād alSaltana," in Dāyirat al-ma'ārif-i buzurg-i islām̄̄ , vol. 9 (Tehran, 1379/2000), 350-54; Abbas Amanat, "E'teżād al-Salțana, 'Alīqolī Mīrzā," in Enycyclopaedia Iranica, vol. 8 (1998), 669-72, available online at http://www.iranicaonline.org/articles/etezad-al-saltana. For more information on the Dar al-Funun, see John Gurney and Negin Nabavi, "Dār alFonū n," in Encyclopaedia Iranica, vol. 6 (1993), 662-68, available online at http://www.iranicaonline.org/articles/dar-al-fonun-lit.

6. Mahdī Bāmdād, Sharḥ-i hạal-i rijāl-i Irān: Qurun 12, 13, 14 hijrī, vol. 3 (Tehran, 134757/1966-78), 449.

7. Abu'l Ḥasan 'Alavī, Rijāl-i 'așr-i mashruțiyat, ed. Habib Yaqmayi and Iraj Afshar (Tehran, 1363/1984-85), 88.

8. See Yāqūt al-Ḥamawī, Mu'jam al-buldān, 8 vols. (Beirut, 1997), 3:446. Mu'jam albuldān is a vast thirteenth-century geographical encyclopedia that summarizes nearly all medieval knowledge. Its wide-ranging information includes archaeology, ethnography, history, anthropology, natural sciences, geography, and the coordinates of places listed. The work gives the various names by which towns and cities were known and describes their monuments, wealth, history, and population.

9. Mirza Husayn Khan Mushir al-Dawla Sipahsalar (1828-81) was Nasir al-Din Shah's reform-minded chancellor between 1871 and 1873, and founded the Sipahsalar mosque and madrasa. See Ghulām Husayn Muṣaḥib, "Husayn Khān Sipahsālār," in vol. 1 of Dāyirat al-ma 'ārif-i fārsī, 3 vols. (Tehran, 1345-74/1966-95); Ibrahīm Taymurī, "Chahā 
rrāh-i sarchishma-i Tihrān," Bukhārā 76 (2010): 132-58; Bāmdād, Sharḥ-i ḥāl-i rijāl-i Irān, 406-26.

10. This madrasa was a center for theological studies; with its mosque, it made up part of the Baharistan building complex in Tehran. Construction was commissioned by Mirza Husayn Khan Mushir al-Dawla in 1896 and was completed after his death by his brother, Mirza Yahya Khan Mushir al-Dawla. Since $1978 / 79$ it has been known as Madrasa-i ' $\bar{A} \bar{I}$ -i Shah $\bar{I} d$ Muțahharī. Its architecture and tilework are typical of the Qajar period, and its library is well known. See 'Ali-Akbar Sa 'idi Sirjani, "Bahārestān," in Encyclopaedia Iranica, vol. 3 (London, 1989), 480-81, available online at http://www.iranicaonline.org/articles/baharestan-central-tehran; Farāmarz Pārs̄ì, "Bahā ristān,” in Dāyirat al-ma 'ārif-i buzurg-i Islām Ī, vol. 13 (Tehran 1383/2005), 96-99.

11. The literal translation from Persian is "book of maps."

12. The Frenchman Alexandre Brongniart (1770-1847) was a Parisian mineralogist, geologist, naturalist, and chemist. He was a professor of natural history at the École de Mines de Paris from 1797. In 1800, based on Brongniart's background in mineralogy, Napoleon's minister of the interior appointed him director of the Sèvres Porcelain Factory, a post he retained until his death. Brongniart also founded the Musée National de Céramique, Sèvres. He was elected to the Académie des Sciences in 1815 , and was professor of mineralogy at the Museum of Natural History in Paris from 1822 to 1847 . His work changed the study of geology in nineteenth-century Europe, and his contributions to the field are credited to this day. Brongniart's last major work, Traité des arts céramiques ou des poteries: Considérées dans leur histoire, leur pratique, et leur théorie 
(Paris, 1844), established the basic principles of ceramic chemistry. In ceramic science, he discovered and established an important rheological formula that bears his name and is still used in manufacturing. His extensive writing included treatises on mineralogy, natural history, and ceramic chemistry; he is particularly known for his scientific and administrative work at the Sèvres porcelain manufactory. In addition he was an art historian and musicologist. See Julia A. Carr-Trebelhorn, "From Geology to Art History: Ceramist Alexandre Brongniart's Overlooked Contribution to the Developing Science of Art History in the Early Nineteenth Century" (MA thesis, University of Kentucky, 2014), http://uknowledge.uky.edu/art etds/4.

13. Alexandre Brongniart, Coloring and Decoration of Ceramic Ware, with notes and additions by Alphonse Salvétat, trans. George J. M. Ashby (Chicago: Windsor and Kenfield, 1898).

14. Louis Marc Emmanuel Solon, Ceramic Literature: An Analytical Index (London: Charles Griffin, 1910), s.v. "Borngniart et Malaguti," 56.

15. As cited in Carr-Trebelhorn, "From Geology to Art History," 5.

16. During the Qajar period the country was called Persia. The name of the country was changed in 1935 from Persia to Iran.

17. See Ina Reiche et al., "Development of a Non-Destructive Method for Underglaze Painted Tiles-Demonstrated by the Analysis of Persian Objects from the Nineteenth Century," Analytical and Bioanalytical Chemistry 393 (Feb. 2009): 1025-41; Lore Troalen et al.,

"'To Acquire a Good Name': Specimens of 19th-Century Persian Tile-Making from the Tehran Workshop of the Master Potter Ali Muhammad Isfahani," in Sources and 
Serendipity: Testimonies of Artists' Practice, ed. Erma Hermens and Joyce H. Townsend (London: Archetype, 2009), 119-27; Ina Reiche and Friedrike Voigt, "Technology of Production: The Master Potter 'Ali Muhammad Isfahani: Insights into the Production of Decorative Underglaze Painted Tiles in 19th Century Iran," in Analytical Archaeometry, ed. Howell Edwards and Peter Vandenabeele (Cambridge: Royal Society of Chemistry, 2012), 502-31.

18. Arthur Lane, Later Islamic Pottery: Persia, Syria, Egypt, Turkey (London: Faber and Faber, 1971), 77.

19. Oliver Watson, Ceramics from Islamic Lands (London: Thames and Hudson in association with the al-Sabah Collection, 2004), 64.

20. Oliver Watson, "Almost Hilariously Bad: Iranian Pottery in the Nineteenth Century," in Islamic Art in the 19th Century: Tradition, Innovation, and Eclecticism, ed. Doris BehrensAbouseif and Stephen Vernoit (Leiden: Brill, 2006), 333-62, at 340.

21. See Jennifer M. Scarce, "Ali Mohammed Isfahani, Tilemaker of Tehran," Oriental Art 22, no. 3 (1976): 278-88, and her "Function and Decoration in Qajar Tilework," in Islam in the Balkans: Persian Art and Culture of the 18th and 19th Centuries, ed. Jennifer M. Scarce (Edinburgh: Royal Scottish Museum, 1979), 75-86.

22. See note 4 above.

23. Watson, "Almost Hilariously Bad," 340-42. 


\section{ILLUSTRATIONS}

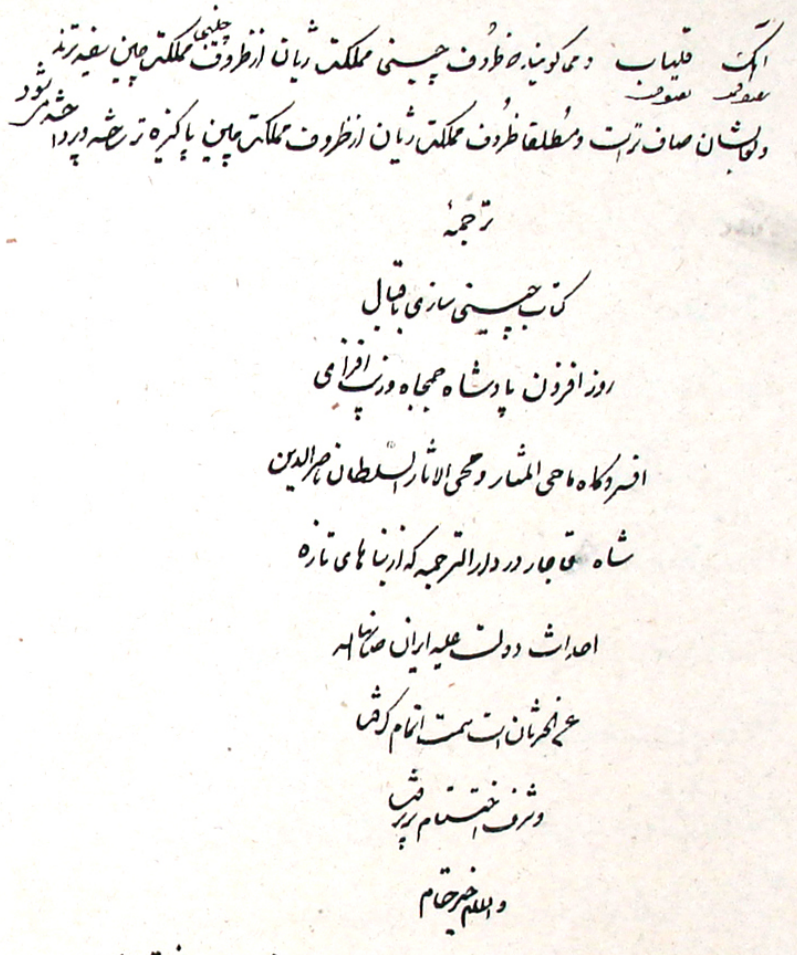

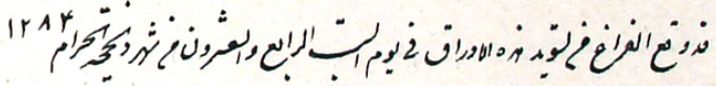

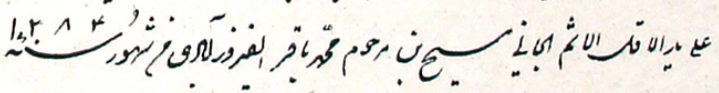

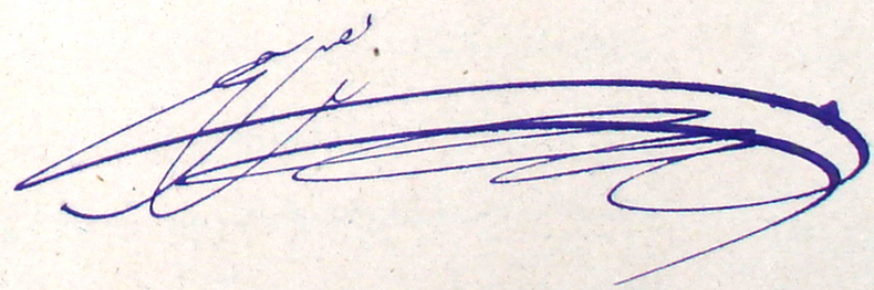


Fig.1: The colophon, Risa-la dar tafșill-i sa-khtan-i chīnī, Tehran, Sipahsalar Library, Ms. 2833, fol. 61b (Photo: courtesy of the Sipahsalar Library). 


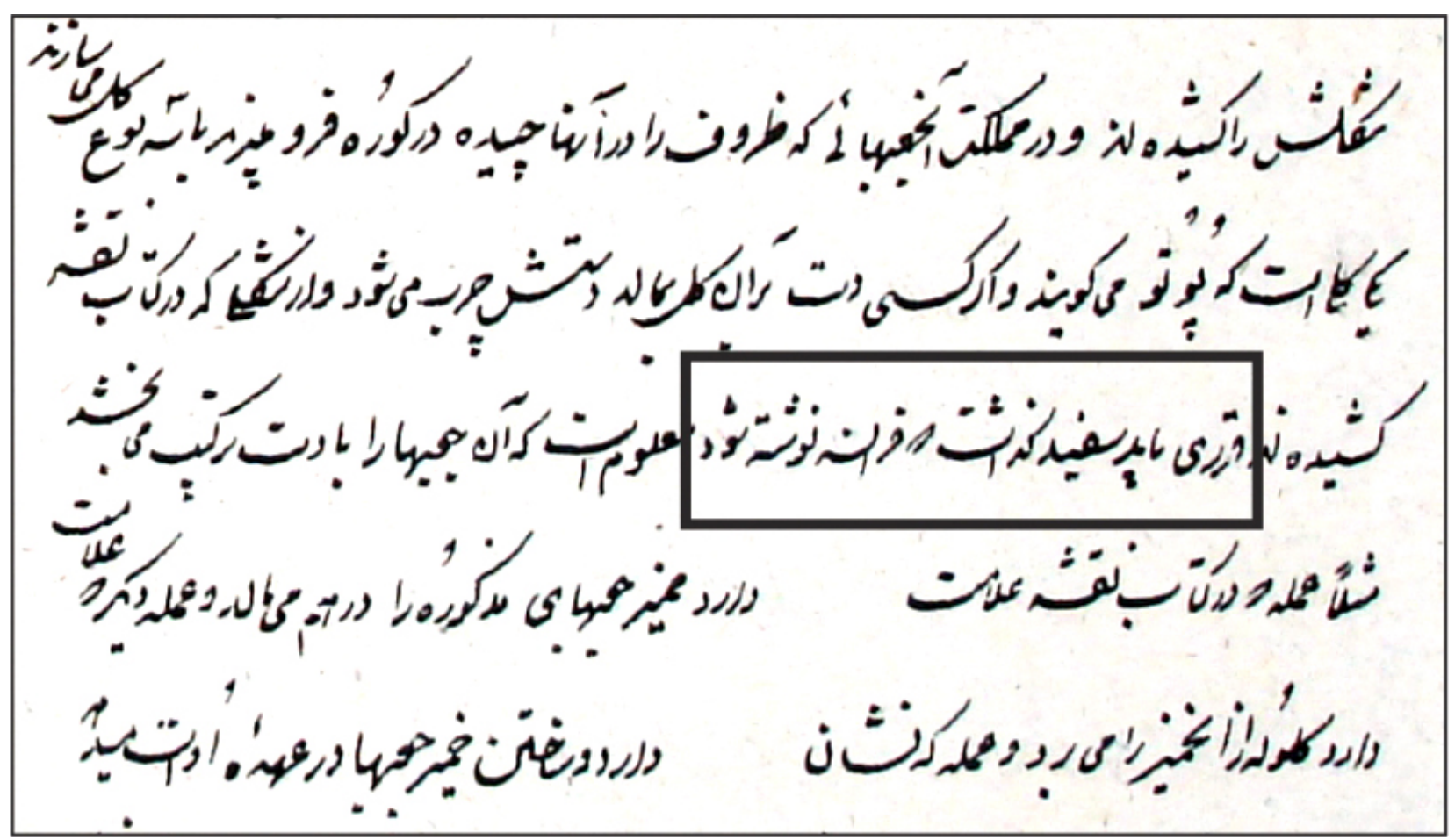

Fig.2: Details of fol. 60b, lines 10-14, Risa-la dar tafșini sa-khtan-i chīnī, Tehran, Sipahsalar Library, Ms. 2833 (Photo: courtesy of the Sipahsalar Library, modified by Mahmoud Nader). 


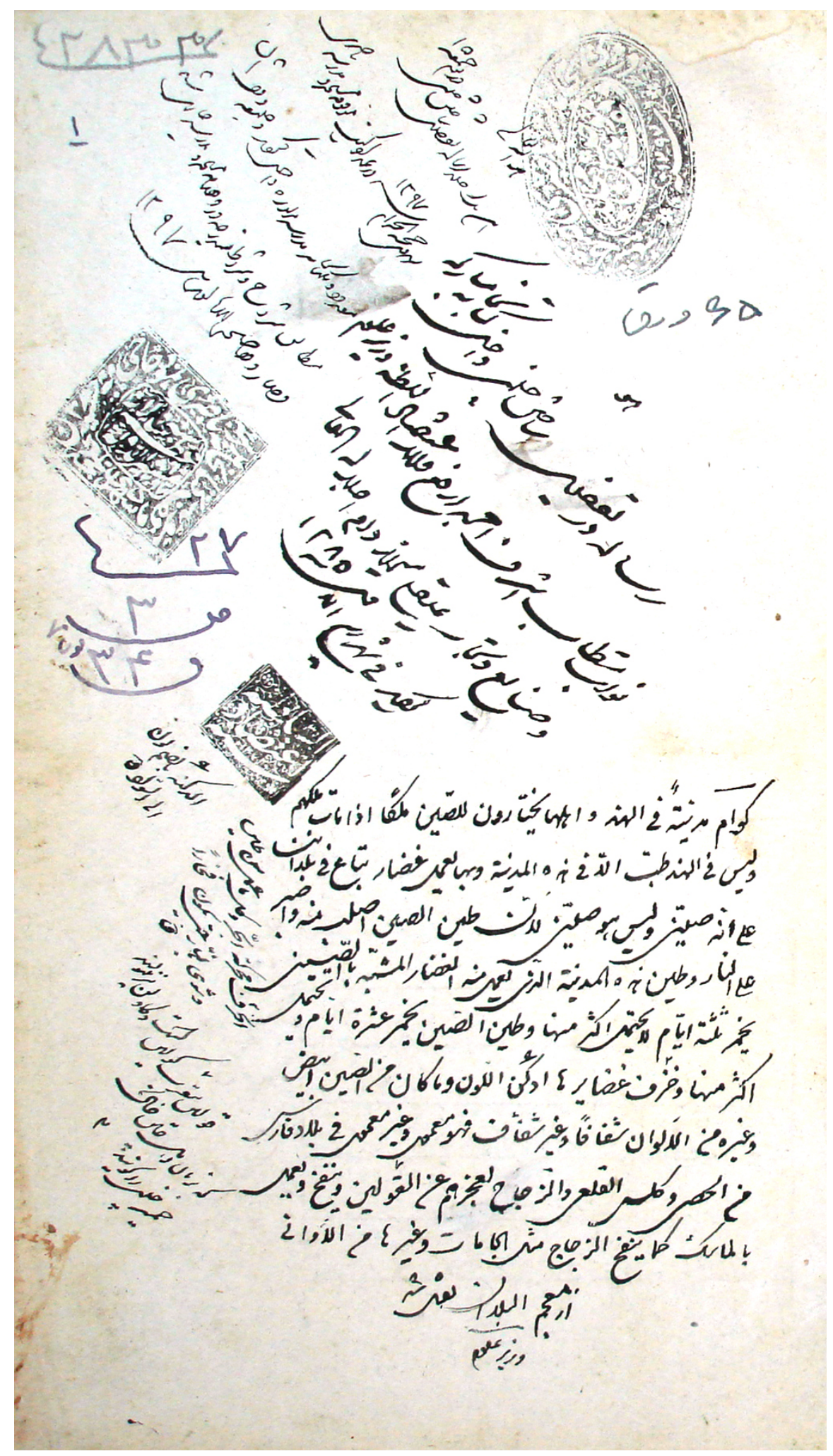


Fig. 3. Fol. 1a, Risa-la dar tafșīl-i sa-khtan-i chīnī, Sipahsalar Library, Ms. 2833 (Photo: courtesy of the Sipahsalar Library). 


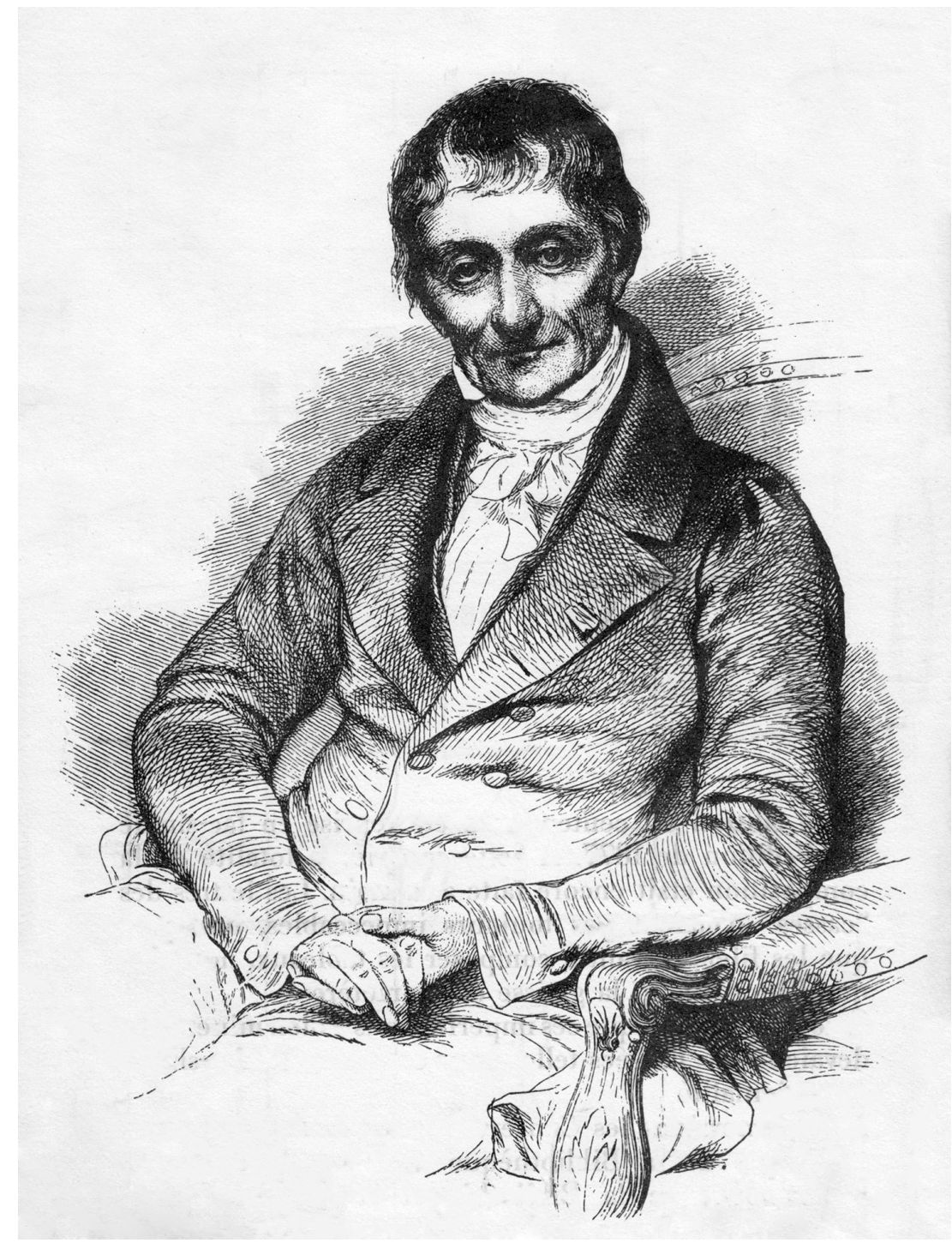

Fig. 4. Alexandre Brongniart (After A. Brongniart, Arts Céramiques, Paris, 1877. 


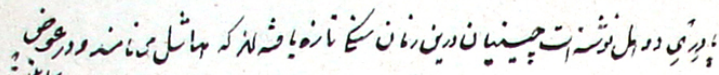

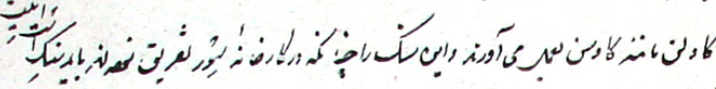

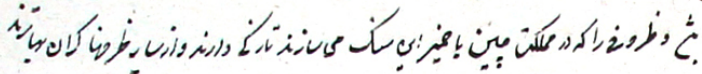

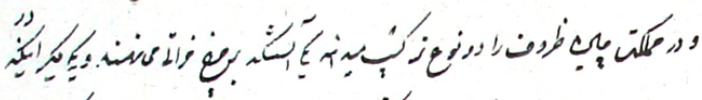
تابل

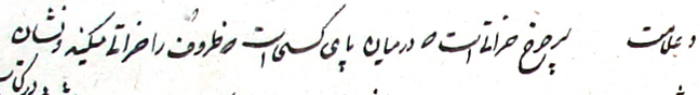

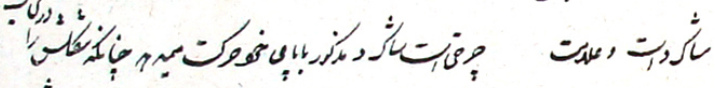

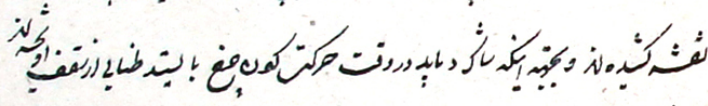

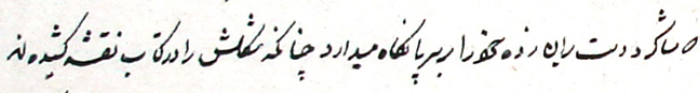

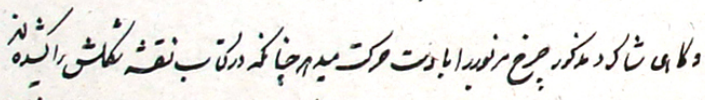

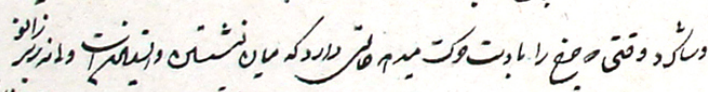

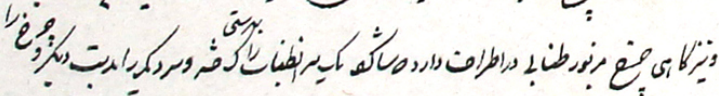

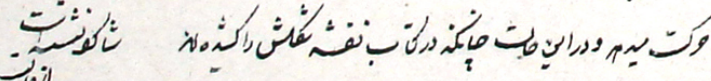

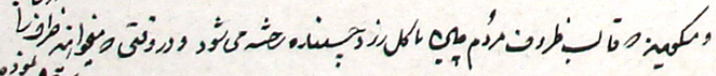
.

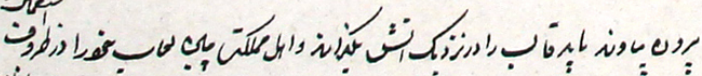
לرنش ה

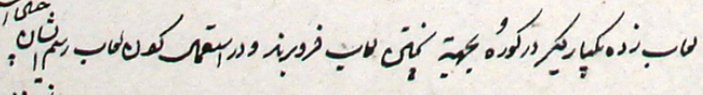
" 
Fig. 5. Fol. 60a, Risa-la dar tafșil-i sa-khtan-i chīnī, Tehran, Sipahsalar Library, Ms. 2833 (Photo: courtesy of the Sipahsalar Library). 

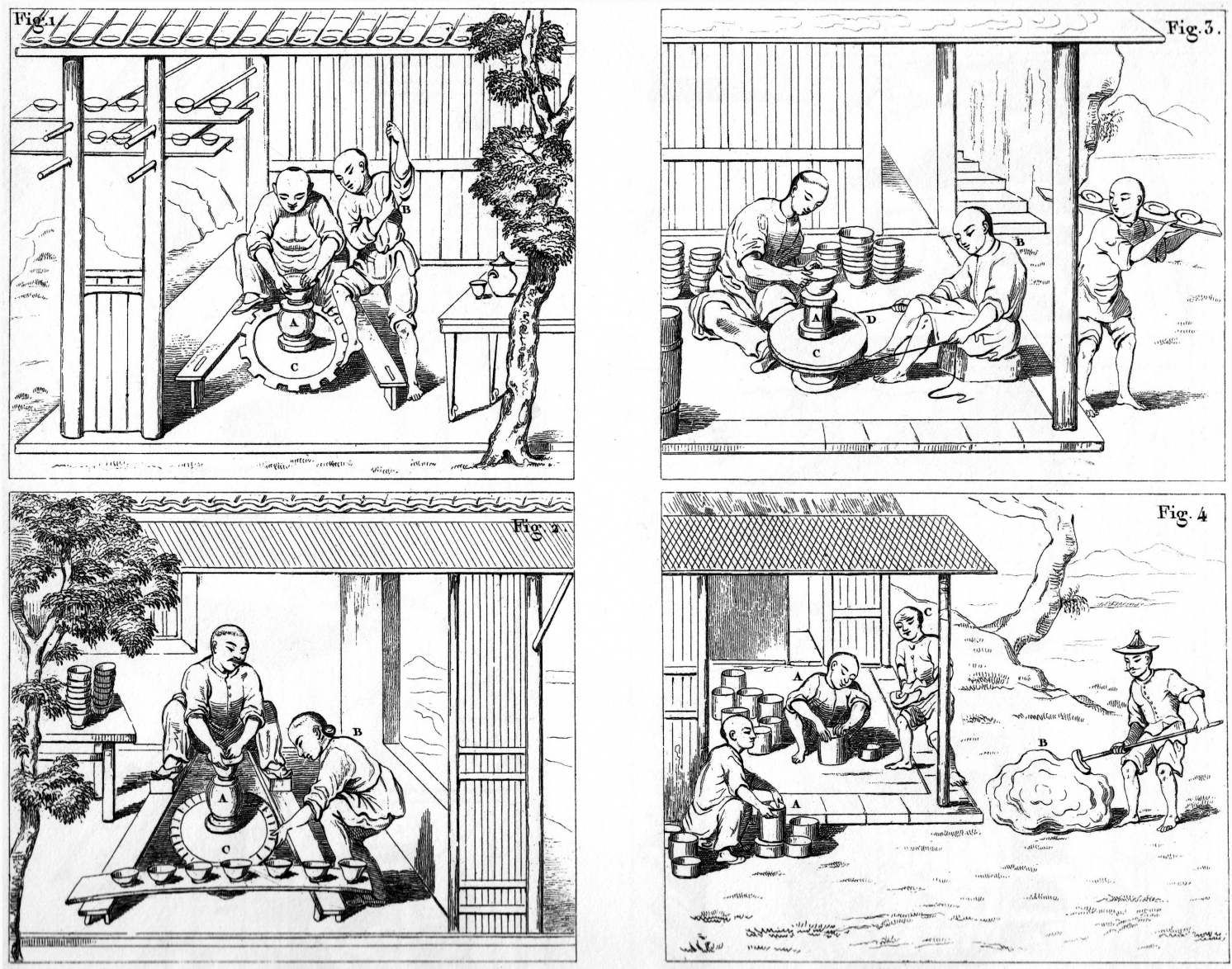

Fig. 6. The Atlas, Plate XLIII, "Fabrication de la Porcelaine en Chine" (After A. Brongniart, The Atlas, Paris, 1877). 